\title{
Kültür Deniz Balıkları İşleme Artıklarından Elde Edilen Balık Yağı ve Silajının Bazı Kalite Özellikleri
}

\author{
Fatma YAMUÇ ${ }^{1}$ iD, Ali GÜNL $\ddot{U}^{2 *}$ \\ ${ }^{1}$ Muğla S1tkı Koçman Üniversitesi, Fen Bilimleri Enstitüsü, Muğla \\ ${ }^{2}$ Muğla S1tkı Koçman Üniversitesi, Su Ürünleri Fakültesi, Muğla \\ *Sorumlu yazar: aligunlu@mu.edu.tr
}

Geliş 05 Mart 2021; Kabul 15 Nisan 2021; Basım 01 Aralık 2021.

Alıntılama: Yamuç, F., \& Günlü, A. (2021). Kültür deniz balıkları işleme artıklarından elde edilen balık yağı ve silajının bazı kalite özellikleri. Acta Aquatica Turcica, 17(4), 515-524. https://doi.org/10.22392/actaquatr.891590

\section{Özet}

Çalışmada, kültür deniz balıkları işleme endüstrisi artıklarından formik asit hidrolizi ile balık silajı ve balık yağı üretilmesi, elde edilen ürünlerin kimyasal ve mikrobiyolojik kalitesinin tespiti ve balık yağının yağ asit kompozisyonun belirlenmesi amaçlanmıştır. Bu kapsamda yapılan çalışmalar sonucunda elde edilen balık silajının nem içeriği \% 80,40 , tüm aşamalarda ürün kalitesinin önemli göstergelerinden birisi olan pH değerinin de 3,62 ile 3,89 arasında değişim gösterdiği tespit edilmiştir. Balık silajının kuru ağırlıktaki kuru madde, ham protein, ham yağ ve ham kül değerleri sırasıyla \%19,60, $\% 48,26, \% 15,17$ ve 17,01 olarak bulunmuştur. Ayrıca ürünün toplam mezofilik aerob bakteri, toplam psikrofilik aerob bakteri ve toplam koliform bakteri bakımından güvenli olduğu, üretilen balık yağının toplam doymuş yağ asidi miktarı \%20,64, doymamış yağ asidi miktarı ise \%70,49 olarak belirlenmiştir. Toplam n-3 yağ asidi miktarı \%12,15, toplam n-6 yăg asidi miktarı $\% 19,87$ ve n-3/n-6 oranı da 0,61 olarak saptanmıştır.

Anahtar Kelimeler: Kültür deniz balıkları, balık işleme artı̆̆ı, balık yağı, balık silajı, yağ asidi

\section{Some Quality Characteristics of Fish Oil and Silage Produced From Culture Marine Fish Processing Waste}

\section{Abstract}

It was aimed to produce fish silage and fish oil by formic acid hydrolysis, to determine the chemical and microbiological quality of the products obtained, and to reveal the fatty acid composition of fish oil in this study. The fish silage has a moisture content of $80.40 \%$, and the $\mathrm{pH}$ value, one of the important indicators of the product quality at all stages, has been determined to be between 3.62 and 3.89. Values of the dry weight of the fish silage sample were $19.60 \%$, crude protein $48.26 \%$, crude fat $15.17 \%$, and crude ash $17.01 \%$. In addition, the total mesophilic aerobic bacteria, total psychrophilic aerobic bacteria, and total coliform bacteria safety of the produced fish oil, total saturated fatty acid amount of $20.64 \%$, $70.49 \%$ percent of unsaturated fatty acid was determined. The total amount of n-3 fatty acid was $12.15 \%$, the total amount of n-6 fatty acid was $19.87 \%$ and the n-3 / n-6 ratio was calculated as $0.61 \%$.

Keywords: Cultured marine fish, fish processing waste, fish oil, fish silage, fatty acid

\section{GíRiş}

Su ürünleri işleme artıkları önemli oranda proteine sahip olmasının yanında vitamin, mineral ve değerli yă̆ asitlerini de barındırmaktadır. Artıklar gıda, kozmetik, eczacılık, yem sanayi gibi çeşitli endüstriyel alanlarda kullanılmaktadır. Balık yağı, kollajen, protein hidrolizatı, jelatin, kitin ve kitosan bu ürünlerden say1labilir (Taylor ve Alasalvar, 2002).

Türden türe değişmekle birlikte su ürünlerinin \%20-50'lik kısmı insan gıdası olarak değerlendirilirken, geriye kalan kısmı da artık olarak ortaya çıkmaktadır. Bahsedilen bu artıklar dünya genelinde 20 milyon tona ulaşmak üzere olup uygun şekilde değerlendirilemediği bildirilmektedir (Pal ve Suresh, 2016; Gündüz vd., 2018). Aslında artıklar çeşitli işlemlerden geçirildikten sonra balık yemi, balık silaj1, jelatin, sos, enzim ve yenilebilir film eldesin de kullanılabilmektedirler. Özellikle Norveç’te önemli oranda balık silajı yapılmaktadır. Büyük kısmı işleme yan ürünlerinden oluşmak üzere y1lda yaklaşı1k 140 bin ton balık silaj üretimi gerçekleştirilmektedir (Rustad, 2003; Kılınç, 2007; Gündüz vd., 2018).

Balık artıkları; su ürünleri işleme tesislerinde temizlenen balıklardan geriye kalan kafa, barsak, iç organlar, iskelet gibi kısımları ile diğer isleme teknikleriyle islenmiş (dumanlanmış, tuzlanmış, 
konserve, marinat vb.) balıklardan geriye kalan kısımlardır. Bu katı artıklar oldukça büyük bir protein ve balık yağı potansiyelini oluşturmaktadır.

$\mathrm{Su}$ ürünleri yetiştiriciliğinde maliyet ve verimliliği etkileyen unsurların başında balık yemi gelmektedir. Balık yemleri, balık türlerine ve büyüklüklerine göre farklı oranlarda protein içermektedir. Yemlerde istenilen düzeyde protein miktarını sağlamak amacı ile yüksek miktarda protein içeren yem ham maddeleri yoğun bir şekilde kullanılmaktadır.

Balık silajı, bütün veya kıyılmış şekildeki balık etlerinin belli orandaki asitlerle işlenmesi ve enzimlerin aktivitesi sonucu elde edilen ve hayvan beslenmede protein kaynağı olarak kullanılan yem hammaddesidir (Güllü vd., 2015; Gündüz vd., 2018). Balıkların yenilmeyen kısımları ve ekonomik değeri düşük balıklar kullanılarak da balık silajı üretilebilmektedir (Kılınç, 2007; Gündüz vd., 2018). Balık unu ile kıyaslandığında daha ucuz olduğu için kanatlı ve büyük baş hayvan yemi üretiminde yaygın olarak kullanılmaktadır. (Rustad, 2003; Mol, 2004; Goddard ve Perret, 2005; 2005; Kılınç., 2007; Borghesi vd., 2008).

Balık silajı ekonomik değeri düşük balıklar, yan ürünler ve işleme artıklarının karışımlarına \%23'lük formik asit ilavesi sonrası oda sicaklığında bekletilerek, balık dokusundaki endojen enzimlerin faaliyetlerinin maksimum seviyeye çıkarılmasıyla gerçekleştirilir. Karışım 2 gün boyunca $30-40^{\circ} \mathrm{C}$ 'de depolanarak balık dokusundaki istenilen çözünme sağlanmış olur. İdeal hazırlanmış balık silajı karışımının $\mathrm{pH}$ değeri, balık pepsinlerinin optimum aktivite gösterdiği pH aralığı olan 3-4 aralığıdır. Balık silajları doğrudan hayvan yemi olarak kullanılabilir ya da yağları ayrılarak protein içeriği artırılmış ürün olarak da değerlendirilebilir. Düşük yatırım maliyeti ve basit işleme ekipmanlarının kullanılması gibi üretim avantajların vardır. En önemli dezavantajı yüksek su içeriği nedeniyle depolama ve nakliye zorluklarıdır. Buna rağmen ekonomik değeri düşük balıklardan ve işleme artıklarından silaj eldesi ile; su ürünleri tarafından sevilerek tüketilen, sindirilebilirlik değeri yüksek, hijyenik açıdan güvenilir yemlerin üretilmesi önemini artırmaktadır (Kılınç, 2007; Güllü vd., 2015; Gündüz vd., 2018).

Balık silajı, Norveç’te daha çok kürk hayvanları yemi olarak kullanılırken sonradan somon yetiştiriciliğinde kullanılmaya başlanmış ve iyi sonuçlar elde edildiği bildirilmiştir (Çakl1 2008; Çolakoğlu ve Künili, 2016; Jónsson ve Viðarsson, 2016). Balık silajı üretiminde daha çok endüstriyel pelajik balıklar (çaça, ringa balığı gibi) ve balık işleme artıklarının hammadde olarak kullanıldığı, istenilen $\mathrm{pH}$ aralığının sağlanmasında genellikle formik asit kullanıldığı bildirilmiştir (Archer vd., 2001).

Rustad (2003), dünyada her y1l 91 milyon tondan fazla balık ve kabuklu deniz ürünleri avlanmakta olduğu, avcılığın sadece \%50-60'nın insan tüketimi için kullanıldığı, geriye kalan artıkların az bir kısmının yan ürünlerin eldesinde kullanıldığı ve çok büyük miktarının ise israf edilmekte olduğu bildirilmiştir. Bu çalışmada, Norveç'te morina balıkçılığından toplam 232.000 ton yan ürün elde edildiği, bu yan ürün üretiminin 125.000 tonunun kullanılmadan atıldığı ve 107.000 tonunun ise değerlendirildiği bildirilmiştir. İnsan tüketiminde toplam miktarın yaklaşı \% $\% 15,5$ 'ini oluşturan yalnızca 36.000 ton yan ürün kullanılmıştır. Geri kalan balık unu, silaj ve hayvan yemi üretiminde kullanılmıştır. Balık silajı balık unu ile kıyaslandığında daha ucuz olması nedeniyle kanatlı ve büyük baş hayvan üretiminde daha yaygın olarak kullanıldığı belirtilmiştir (Rustad, 2003).

Gıdaların işlenmesi ile ortaya çıkan artıkların iyi bir şekilde değerlendirilmesi, çevresel artık birikimlerinin önlenmesi, sektörel çeşitliliğin artması ve ürün değerinin zenginleştirilmesi konusunda önemli bir yere sahiptir. Ülkemizde, son yillarda ki su ürünleri üretim artışına paralel olarak gelişen su ürünleri işleme endüstrisi ile hem yetiştiricilik hem de avcılık kaynaklı su ürünleri taze, dondurulmuş, iç organları çıkarılıp işlendikten sonra iç ve dış pazarlara sunulmaya başlanmıştır. Bu bağlamda su ürünleri işleme endüstrisi artıklarının önemli bir kısmını oluşturan baş, barsak, iç organların büyük bir kısmı ekonomik anlamda kullanılamadan atılmakta, çok az bir kısmı ise yem hammaddesi üretiminde kullanılabilmektedir. Bu çalışma ile kültür balığı işleme artıklarından asit hidroliz yöntemiyle balık yağı ve balık silajının eldesi, silajın mikrobiyolojik ve kimyasal kalitesinin belirlenmesi yanı sıra silaj üretim işlemi sonucunda elde edilen balık yağının yağ asit kompozisyonun ortaya çıkarılması amaçlanmıştır. Ayrıca ülkemiz kültür balığı sektörünün en önemli sorunlarından biri olan balık unu yerine kullanılabilecek hidrolize balık proteini üretimi ile artıkların ülke ve bölge ekonomisine kazandırılmasına katkı sunulması da hedeflenmektedir. 


\section{MATERYAL ve YÖNTEM \\ Materyal}

Araştırmada kullanılan kültür deniz balıkları (levrek ve çipura) işleme artıkları (kafa, omurga, yüzgeç, kırpıntı et ve deri parçaları) Bodrum/Muğla bölgesinde bulunan yerel işleme fabrikalarından temin edilmiştir. Artıklardan bölgede kurulu balık yemi üretim tesisinde kimyasal yöntemle üretilen balık yağı ve balık silajı örnekleri strafor kutu içerinde soğuk zincir uygulamasıyla, vakit geçirilmeden Muğla Sitkı Koçman Üniversitesi, Su Ürünleri Fakültesi, Su Ürünleri İşleme Teknolojisi Kalite Kontrol Laboratuvarına getirilmiştir. Örnekler kalite-kontrol analizleri yapılıncaya kadar $-85^{\circ} \mathrm{C}^{\prime} l i k$ ultra derin dondurucuda (Daihan WUF500, Korea) saklanmıştır.

\section{Yöntem}

Fileto işlemi sonrası kalan ham balık artıkları (3.000 kg levrek ve çipura) vakum sistemi ile çekilerek hiçbir işlemden geçirilmeden doğrudan içerisinde kesici bıçaklar bulunan parçalayıcılı silaj tankına (Kayaoğlu Makine, Türkiye) alınmıştır. Tankın içine, \% 0,85'lik formik asit (SoftAcid S E236) 100L ilave edilmiş ve yaklaşık 10 saat sürekli sağdan sola karıştırılarak homojen bir parçalanmanın gerçekleşmesi sağlanmıştır. Formik asit kullanılarak gerçekleştirilen asit hidroliz işleminden sonra kemik ayırıcı (Kayaoğlu Makine, Türkiye) ile üründen kemik parçaları ve $5 \mathrm{~mm}$ üzerindeki partiküller ayrılmış, hidroliz edilmiş balık artı̆g 2 tonluk ana hidroliz stok tankına pompalanmıştır. $\mathrm{Bu}$ aşama asit hidroliz aşaması olarak adlandırılmışırı. Hidroliz stok tankına alınmış asit hidroliz sıvısına oksidasyonu engellemek için 1000 kg'a 1 litre Bütil Hidroksi Toluen (BHT) ilave edilmiştir. Karışımın hidroliz stok tankında 3-4 saat süreyle kendi içinde sirkülasyon yaparak homojen kalması sağlanmıştır. Hidroliz stok tankına alınan süspansiyonun başlangıç $\mathrm{pH}$ değeri 6,4-7,0 değerinden $\mathrm{pH}$ 3,5-4 seviyelerine düşmesi asit ilavesi ile sağlanmıştır. Her biri $250 \mathrm{~kg}$ kapasiteli pişirme reaktörlerinde karışım 4'e ayrılarak üzerlerine $2 \mathrm{~kg}$ formik asit ilave edilmiş ve $90^{\circ} \mathrm{C}$ 'de 60 dakika ısıl işlem uygulanmıştır. Isıl işleme maruz bırakılan hammadde 5 tonluk kapasitesi olan ve ürünün sıcaklığını 75-80 ${ }^{\circ} \mathrm{C}$ aralığında tutabilen ana stok tankına aktarılmıştır. Ana stok tankından yüksek devirli dekantöre karışım aktarılarak balık artığının sıvı (yağ+protein sıvısı) ve katı (protein katı partikülü) olmak üzere iki faza ayrılma işlemi gerçekleştirilmiştir. Dekantör santrifüjle süspanse örnek, yağlı su fazı ve yoğun hidrolize protein fazı olarak ayrılmıştır. Ayrılan yağlı su fazı içeren kısım pompa ile seperatöre aktarılmış, separatöre $70{ }^{\circ} \mathrm{C}$ sıcaklıkta su girişi yapılarak yüksek hızda santrifüj işlemi aracılığıyla su ile balık yağının birbirinden ayrılması sağlanmıştır. Separatörde ayrılan balık yağı, yağ geçiş tankına boru ile aktarılmış (Şekil 1.a), sıvı faz ise bir önceki aşamada çıkan yoğun proteinize faz ile birleştirilmiştir (Şekil 1.b). Bu aşama da elde edilen ürün balık silajı olarak isimlendirilmiştir. Balık silajı ve yağ 1 üretim akış şeması Şekil 2'de verilmiştir. Bu dört aşamadan alınan örneklerde $\%$ nem, $\%$ ham protein, $\%$ ham yağ, $\%$ ham kül ve $\mathrm{pH}$ analizleri yapılmıştır $(\mathrm{n}=6)$. Ayrıca son aşamada elde edilen hidrolize protein sıvı fazı liyofilize edilerek kurutulmuş ve kurutulmuş örnekte mikrobiyolojik analizler gerçekleştirilmiştir $(n=2)$. İşlem sonucunda elde edilen balık yağı ise yağ asit kompozisyon analizine tabi tutulmuştur $(n=2)$.

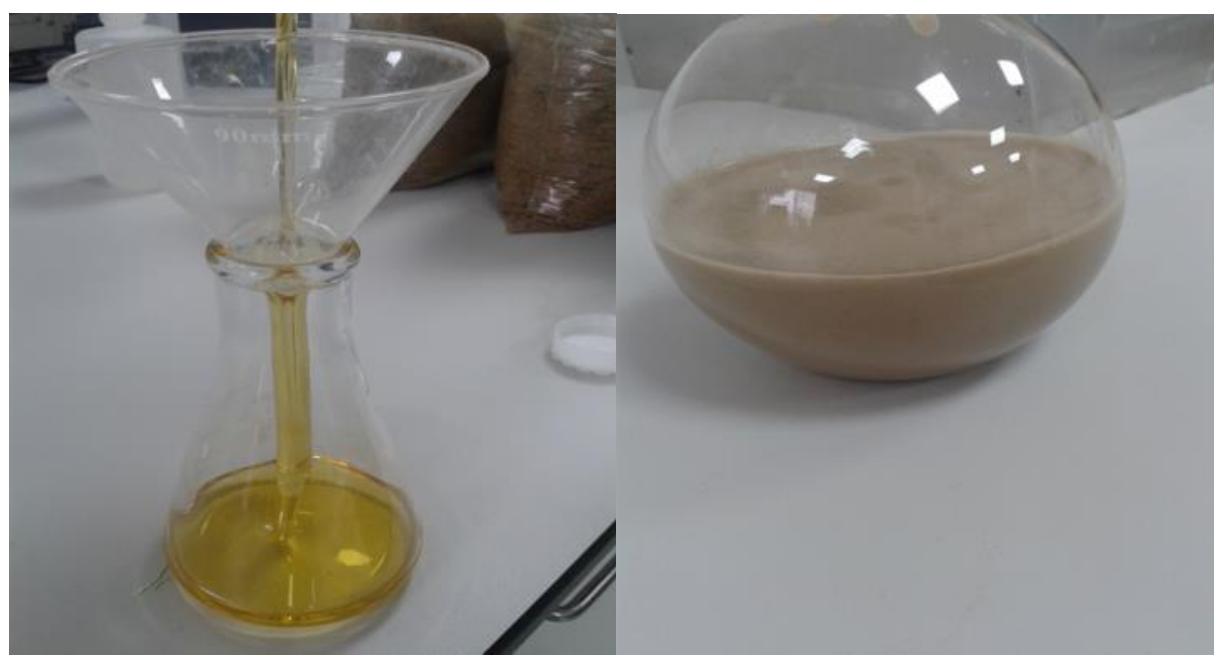

Şekil 1. a) Balık yağı fazı, b) Balık silajı 


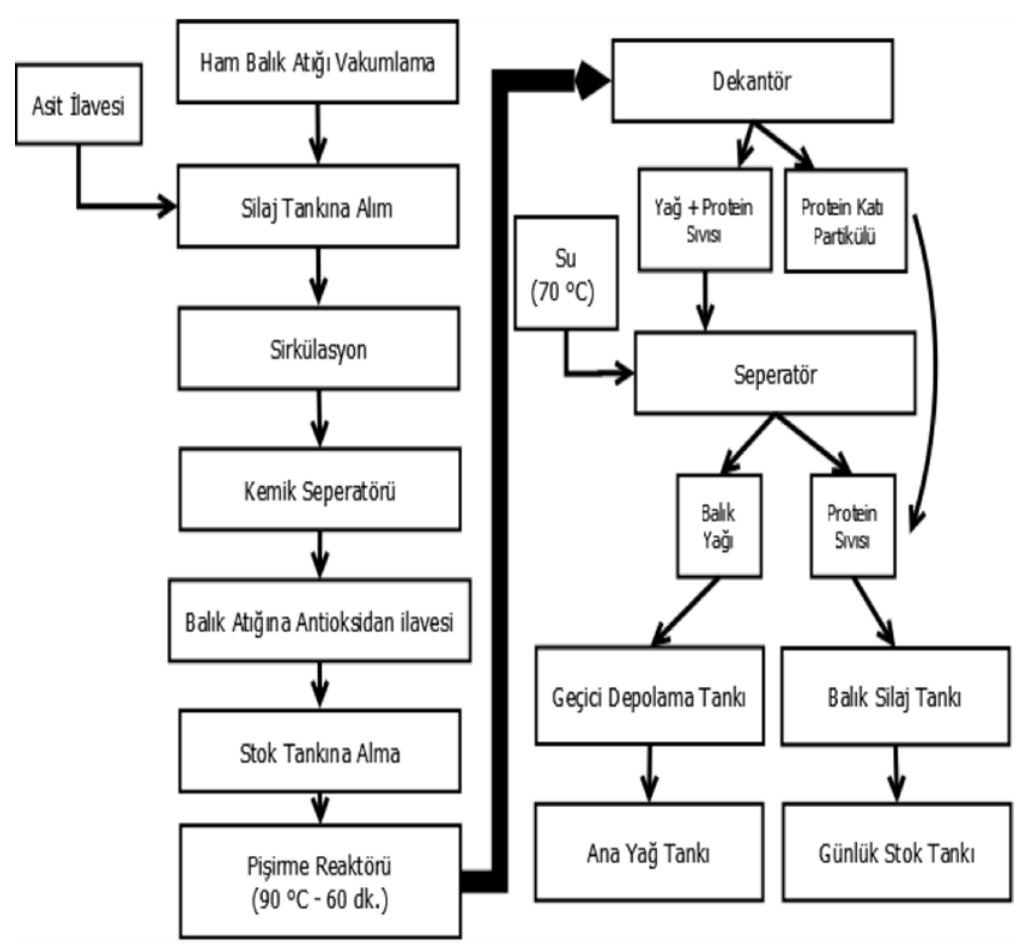

Şekil 2. Balık artığı işleme akış şeması

\section{Kimyasal Kompozisyon Analizleri}

Çalışmada elde edilen balık silajının nem miktarı tayini AOAC (1990), ham protein miktarı AOAC (2005a), ham yağ miktarı (Sokshlet Metodu) AOAC (2005b) ve ham kül tayini AOAC (1990) metotları esas alınarak yapılmıştır.

\section{Liyofilize Balık Silajı Örneklerinin Mikrobiyolojik Analizleri}

Mikrobiyolojik analizler kapsamında liyofilize edilen balık silajı örneklerinde toplam mezofilik aerob, toplam psikrofilik aerob ve toplam koliform bakteri sayısı belirlenmiştir. Toplam mezofilik aerob ve toplam psikrofilik aerob bakteri sayısı analizleri için aseptik koşullarda balık silajı örneğinden $10 \mathrm{~g}$ alınıp steril stomacher poşetlere (Bagmixer intersince) konulmuş, üzerine $90 \mathrm{ml} \%$ 0,1 steril peptonlu su (Merck) ilave edilip stomacherde homojenize edilerek $10^{-1}$ lik dilisyon elde edilmiştir. İstenilen seyrelti oranına kadar 9'ar ml steril peptonlu su içeren tüplere her bir önceki dilisyondan 1'er ml eklendikten sonra tüpler vorteks (X620, CAT) ile iyice çalkalanarak seri dilüsyonlar oluşturulmuştur. Toplam koliform bakteri sayısının belirlenmesi için aseptik şartlar altında $10 \mathrm{~g}$ örnek içinde $90 \mathrm{ml}$ MRD (Maksimum Recovery Diluent) çözeltisi olan şişelere eklenmiştir. Bu karışım stomacherda $2 \mathrm{dk}$ homojenize edilmiştir. Bu şekilde hazırlanan $10^{-1}$ 'lik dilüsyondan deney tüplerine $10^{-2}-10^{-7}$ lik diğer dilüsyonlar hazırlanmıştır. Her bir dilüsyondan çift paralelli olarak steril petri kaplarına dökme plak yöntemlerinde $1 \mathrm{ml}$, yayma plak yöntemlerinde $0,1 \mathrm{ml}$ ekim yapılmıştır (Varlık vd 1993, Akçelik vd 2000, Ünlütürk ve Turantaş 2002, Sekin ve Karagözlü 2004).

Toplam mezofilik aerob bakteri ve toplam psikrofilik aerob bakteri sayıs Plate Count Agar (Merck)'lı besi yerinde sirasıyla $37^{\circ} \mathrm{C}$ 'de $24-48$ saatlik ve $7^{\circ} \mathrm{C}$ 'de 10 günlük inkübasyon sonucunda, toplam koliform bakteri sayıs ise Violet Red Bile Agar (Merck)' 11 besi yerinde $37^{\circ} \mathrm{C}$ 'de $24-48$ saatlik inkübasyon sonucunda petrilerde gelişen bütün kolonilerin standart şekilde sayımı ile hesaplanmıştır (FAO, 1992).

\section{Balık Yağında Yağ Asidi Kompozisyonu Analizi}

Örneklerin yağ asitleri kompozisyonu gaz kromatografisi-alev iyonlaştırıcı detektör (GC-FID) kullanılarak belirlenmiştir. Ham yağ örneklerinin belirlenmesinde Bligh ve Dyer (1959) yöntemi kullanılmış ve elde edilen yağlar $4 \mathrm{ml} 2 \mathrm{~N}$ potasyum hidroksit eklendikten sonra vorteks ile $1 \mathrm{dk}$ karıştırılmış ve $2 \mathrm{ml}$ isooktan eklenerek metillendirme işlemi yapılmıştır. Daha sonra vorteks ile $1 \mathrm{dk}$ karıştırılmış ve $+4^{\circ} \mathrm{C}$ 'de 4000 rpm'de $10 \mathrm{dk}$ santrifüj edilmiştir. Süpernanant kısmı ependorf tüplerine alınarak gerekli olduğu durumda $1 / 3$ oranında isooktan ile seyreltme uygulanmıştır (Ichihara vd., 1996). Örnekler GC cihazına verilinceye kadar $-85^{\circ} \mathrm{C}$ (Daihan WUF500, Korea)'de saklanmıştır. Metil 
esterlerine dönüştürülen yağ asitleri Agilent 7820 GC model gaz kromatografi cihazında FID detektörü ile HP-88 kapiler kolon $(60 \mathrm{~m}, 0.25 \mathrm{~mm}$ ID ve $0.25 \mu \mathrm{m})$ kullanılarak analiz edilmiştir. Sırasıyla enjektör ve detektör sıcaklıkları ile $220^{\circ} \mathrm{C}$ sonra $280^{\circ} \mathrm{C}^{\prime}$ ye ayarlanmıştır. $\mathrm{Bu}$ sırada firın sicaklığ $140{ }^{\circ} \mathrm{C}$ 'de 5 dakika tutulmuştur. Sonrasında $200{ }^{\circ} \mathrm{C}$ 'ye kadar, her dakika $4{ }^{\circ} \mathrm{C}$ arttırılarak, $200{ }^{\circ} \mathrm{C}$ 'den $220^{\circ} \mathrm{C}$ 'ye de her dakika $1{ }^{\circ} \mathrm{C}$ arttırılarak getirilmiştir. Örnek miktarı $1 \mu 1$ olup, taşıyıcı gaz kontrolü 16 psi'de olması sağlanmıştır. Split uygulaması 1:50 oranında gerçekleştirilmiştir. Yağ asitleri standart 37 bileşenden oluşan FAME (Supelco) karışımının gelme zamanlarına bağlı olarak karşılaştırılmasıyla tanımlanmıştır. Aynı şekilde yapılan iki paralelli GC analiz sonuçları \pm standart hata değerleri ile \% olarak ifade edilmiştir.

\section{İstatistiksel analizler}

İstatistiksel analizler, istatistik paket programı (SPSS for Windows 16.0) kullanılarak yapılmıştır. Çizelge ve şekillerde analiz sonuçları ortalama \pm standart hata $(\mathrm{SH})$ olarak verilmiştir. Çoklu karşılaştırmalar için tek yönlü varyans analizi (ANOVA) uygulanmıştır. Bu test sonucunda önemli farklar bulunan varyans kaynakları arasında Duncan çoklu karşılaştırma testi kullanılmıştır. İstatistiki karşılaştırmalarda önem seviyesi $\mathrm{P}=0.05$ olarak alınmıştır.

\section{BULGULAR}

\section{Kimyasal kompozisyon analiz sonuçları}

Kültür deniz balıkları işleme artıklarından formik asit kullanarak balık silajı üretiminin her aşamasında yaş ve kuru ağırlıkta kimyasal içerikteki değişimleri gösterir analiz sonuçları Tablo 1 ve 2'de verilmiştir.

Tablo 1. Liyofilize balık silajı örneklerinin kimyasal kompozisyon analiz sonuçları (Yaş ağırlıkta)

\begin{tabular}{lccccc}
\hline \hline & NEM & HAM PROTEIN & HAM YAĞ & HAM KÜL & pH \\
\cline { 2 - 6 } & \%ORT \pm SH & \%ORT \pm SH & \%ORT \pm SH & $\%$ ORT \pm SH & OR \pm SH \\
\hline Asit Hidroliz aşamas1 & $55,84 \pm 2,34^{\mathrm{c}}$ & $11,83 \pm 0,27^{\mathrm{b}}$ & $9,11 \pm 0,24^{\mathrm{b}}$ & $5,22 \pm 0,22^{\mathrm{a}}$ & $3,89 \pm 0,02^{\mathrm{a}}$ \\
Ana Stok Tank1 & $62,39 \pm 0,37^{\mathrm{b}}$ & $12,61 \pm 0,16^{\mathrm{a}}$ & $12,71 \pm 1,26^{\mathrm{a}}$ & $4,94 \pm 0,07^{\mathrm{a}}$ & $3,62 \pm 0,06^{\mathrm{b}}$ \\
Yoğun Proteinize Faz & $80,28 \pm 0,44^{\mathrm{a}}$ & $9,95 \pm 0,28^{\mathrm{c}}$ & $4,12 \pm 0,71^{\mathrm{c}}$ & $2,45 \pm 0,06^{\mathrm{c}}$ & $3,67 \pm 0,04^{\mathrm{b}}$ \\
Proteinize Siv1 Faz & $80,40 \pm 0,28^{\mathrm{a}}$ & $9,44 \pm 0,23^{\mathrm{c}}$ & $2,97 \pm 0,32^{\mathrm{c}}$ & $3,34 \pm 0,11^{\mathrm{b}}$ & $3,86 \pm 0,08^{\mathrm{a}}$ \\
\hline \hline
\end{tabular}

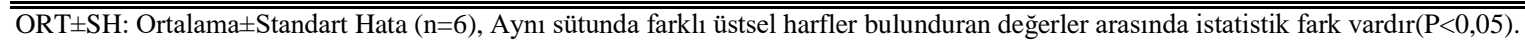

Tablo 2. Liyofilize balık silajı örneklerinin kimyasal kompozisyon analiz sonuçları (Kuru ağırlıkta)

\begin{tabular}{lccccc}
\hline \hline & KURU MADDE & HAM PROTEIN & HAM YAĞ & HAM KÜL & pH \\
\cline { 2 - 6 } & $\%$ ORT \pm SH & $\%$ ORT \pm SH & $\%$ ORT \pm SH & $\%$ ORT \pm SH & ORT \pm SH \\
\hline Asit Hidroliz aşamas1 & $44,16 \pm 2,34^{\mathrm{a}}$ & $27,31 \pm 2,03^{\mathrm{c}}$ & $21,00 \pm 1,46^{\mathrm{b}}$ & $11,96 \pm 0,71^{\mathrm{b}}$ & $3,89 \pm 0,02^{\mathrm{a}}$ \\
Ana Stok Tank1 & $37,61 \pm 0,37^{\mathrm{b}}$ & $33,54 \pm 0,60^{\mathrm{b}}$ & $33,71 \pm 3,16^{\mathrm{a}}$ & $13,13 \pm 0,22^{\mathrm{b}}$ & $3,62 \pm 0,06^{\mathrm{b}}$ \\
Yoğun Proteinize Faz & $19,72 \pm 0,44^{\mathrm{c}}$ & $50,63 \pm 2,13^{\mathrm{a}}$ & $20,62 \pm 3,22^{\mathrm{b}}$ & $12,42 \pm 0,38^{\mathrm{b}}$ & $3,67 \pm 0,04^{\mathrm{b}}$ \\
Proteinize Siv1 Faz & $19,60 \pm 0,28^{\mathrm{c}}$ & $48,26 \pm 1,58^{\mathrm{a}}$ & $15,17 \pm 1,70^{\mathrm{b}}$ & $17,01 \pm 0,45^{\mathrm{a}}$ & $3,86 \pm 0,08^{\mathrm{a}}$ \\
\hline \hline
\end{tabular}

ORT \pm SH: Ortalama \pm Standart Hata (n=6), Aynı sütunda farklı üstsel harfler bulunduran değerler arasında istatistik fark vardır $(\mathrm{P}<0,05)$.

\section{Mikrobiyolojik analiz sonuçları}

Asit hidroliz aşaması sonrası alınan örnek ile son aşamada hidrolize protein aşamasından alınan örnekler dondurulduktan sonra liyofilize edilerek kurutulmuş, liyofilize örneklerde mikrobiyolojik kalite analizleri yapılmıştır. Örneklerin mikrobiyolojik analiz sonuçları Tablo 3'te verilmiştir. Analiz sonuçlarına göre her iki örnek grubunda da toplam koliform ve psikrofil bakterileri bulunmamış, toplam bakteri yükü ise asit hidroliz aşaması örneğinde 5,3 log kob/g; proteinize sıvı faz örneğinde ise $5,7 \log \mathrm{kob} / \mathrm{g}$ olarak tespit edilmiştir.

Tablo 3. Liyofilize balık silajı örneklerinin mikrobiyolojik kalite analiz sonuçları (log kob/g)

\begin{tabular}{cccc}
\hline \hline & T. Mezofilik Aerob Bakteri & T. Psikrofilik Aerob Bakteri & T. Koliform \\
\cline { 2 - 4 } & $\mathrm{ORT} \pm \mathrm{SH}$ & $\mathrm{ORT} \pm \mathrm{SH}$ & $\mathrm{ORT} \pm \mathrm{SH}$ \\
\hline Asit Hidroliz Aşaması & $5,3 \pm 0,05$ & $<1,0 \pm 0,00$ & $<1,0 \pm 0,00$ \\
Proteinize Sıvı Faz & $5,7 \pm 0,04$ & $<1,0 \pm 0,06$ & $<1,0 \pm 0,00$ \\
\hline \hline
\end{tabular}




\section{Yağ asit analiz sonuçları}

Kültür deniz balıkları işleme artıklarından hidrolize balık proteini üretimi sırasında elde edilen balık yağının yağ asit kompozisyonunu belirlemeye yönelik çalışmada 30 farklı yağ asidi belirlenmiş, toplam doymuş yağ asidi miktarı \%20,64, doymamış yağ asidi miktarı ise \%70,49 olarak bulunmuştur. Ayrıca toplam n-3 yağ asidi miktarı \%12,15, toplam n-6 yağ asidi miktarı $\% 19,87$ ve n-3/n-6 oranı $\% 0,61$ olarak hesaplanmıştır (Tablo 4).

Tablo 4. Su ürünleri işleme artıklarından elde edilen balık yağının yağ asit kompozisyonu (\%)

\begin{tabular}{|c|c|c|}
\hline & Yağ asitleri & $\%$ ORT \pm SE \\
\hline 1 & Laurik Asit C12:0 & $0,03 \pm 0,00^{\mathrm{j}}$ \\
\hline 2 & Tridekanoik Asit C13:0 & $0,01 \pm 0,00^{\mathrm{j}}$ \\
\hline 3 & Miristik Asit C14:0 & $2,34 \pm 0,00^{\mathrm{efg}}$ \\
\hline 4 & Miristeloik Asit C14:1 & $0,06 \pm 0,00^{\mathrm{j}}$ \\
\hline 5 & Pentadekanoik Asit C15:0 & $0,32 \pm 0,00^{\mathrm{ij}}$ \\
\hline 6 & Palmitik Asit C16:0 & $13,36 \pm 0,00^{\mathrm{c}}$ \\
\hline 7 & Palmiteloik Asit C16:1 & $1,99 \pm 1.88^{\text {efgh }}$ \\
\hline 8 & Heptadekonoik Asit C17:0 & $0,28 \pm 0,04^{\mathrm{ij}}$ \\
\hline 9 & Steraik Asit C18:0 & $3,22 \pm 0,01^{\mathrm{e}}$ \\
\hline 10 & cis 10 Heptadekonoik Asit C17:1 & $0,39 \pm 0,01^{\mathrm{ij}}$ \\
\hline 11 & Trans Oleik Asit C18:1n9t & $0,20 \pm 0,01^{\mathrm{j}}$ \\
\hline 12 & Oleik Asit C18:1n9c & $32,40 \pm 0,02^{\mathrm{a}}$ \\
\hline 13 & Trans Linoleik Asit C18:2n6t & $0,10 \pm 0,01^{\mathrm{j}}$ \\
\hline 14 & Linoleik Asit C18:2n6c & $19,14 \pm 0,02^{b}$ \\
\hline 15 & Arsidik Asit C20:0 & $0,26 \pm 0,02^{1 j}$ \\
\hline 16 & Gama Linoleik Asit C18:3n6 & $0,15 \pm 0,15^{\mathrm{j}}$ \\
\hline 17 & cis 11 Eikosenoik Asit C20:1n9 & $1,70 \pm 1,49^{\text {fgh } 1}$ \\
\hline 18 & Alfa Linoleik Asit C18:3n3 & $2,11 \pm 0,00^{\mathrm{efg}}$ \\
\hline 19 & Enoikosanoik Asit C21:0 & $0,12 \pm 0,00^{\mathrm{j}}$ \\
\hline 20 & cis 11-14 Eikosadienoik Asit C20:2 & $1,02 \pm 0,00^{\text {ghij }}$ \\
\hline 21 & Behenik Asit C22:0 & $0,22 \pm 0,01^{\mathrm{ij}}$ \\
\hline 22 & cis 8-11-14 Eikosatrienoik Asit C20:3n6 & $0,12 \pm 0,00^{\mathrm{j}}$ \\
\hline 23 & Erucic Asit C22:1n9 & $0,61 \pm 0,07^{\mathrm{hij}}$ \\
\hline 24 & cis 11-14 -17 Eikosatrienoik asit C20:3n3 & $0,61 \pm 0,08^{h i j}$ \\
\hline 25 & Arasidonik Asit C20:4n6 & $0,36 \pm 0,00^{1 j}$ \\
\hline 26 & Trikosanoik Asit C23:0 & $0,21 \pm 0,21^{\mathrm{ij}}$ \\
\hline 27 & cis 5-8-11-14-17 Eikosapentaenoik Asit C20:5n3 & $3,03 \pm 0,02^{\mathrm{ef}}$ \\
\hline 28 & cis 13-16 Dokosadienonik Asit C22:2 & $0,10 \pm 0,00^{\mathrm{j}}$ \\
\hline 29 & Lignoserik Asit C24:0 & $0,27 \pm 0,01^{1 \mathrm{j}}$ \\
\hline 30 & Docosahegzaenoik Asit C22:6n3 & $6,41 \pm 0,00^{\mathrm{d}}$ \\
\hline & $\Sigma$ SFA & 20,64 \\
\hline & $\Sigma U F A$ & 70,49 \\
\hline & $\Sigma$ MUFA & 37,36 \\
\hline & $\Sigma$ PUFA & 33,14 \\
\hline & $\Sigma$ n-6 PUFA & 19,87 \\
\hline & $\Sigma$ n-3 PUFA & 12,15 \\
\hline & $n-3 / n-6$ & 0,61 \\
\hline
\end{tabular}

istatistik fark vardır $(\mathrm{P}<0,05)$.

\section{TARTIŞMA ve SONUÇ}

Türkiye'de çok sayıda su ürünleri işleme tesisi bulunmaktadır. Bunların sayıları ise her geçen gün artmaktadır. $\mathrm{Bu}$ işletmelerde balık artıkları oldukça fazla olup bu artıklar protein ve balık yağı açısından oldukça zengindir. Son yıllarda ülkemizde su ürünleri işleme endüstrisi artıklarının balık yemlerinde balık ununun yerini alabilecek protein içeriği yüksek hidrolize balık proteini ve bu üretim süreci içerisinde elde edilen balık yağı üretimine yönelik ticari işletmeler faaliyete geçmiş bulunmaktadır. 
Ülkemiz balık yetiştirme ve işleme konusunda dünya standartlarını yakalamış ve üstün kalite ve standartlarındaki ürünleri yurt dışı pazarlarına başarıyla sunmaktadır. Buna karşın ülkemizde balık artıklarının fermantasyon yoluyla değerlendirilmesine yönelik çalışmalar ise sınırlı sayıda kalmıştır. Özellikle Danimarka ve Norveç gibi İskandinav ülkelerinde balık silajı üretiminin önemli olduğu bilinmektedir. Balık silajı, Norveç’te çoğunlukla kürk hayvanları için bir yem olarak kullanılırken daha sonra bu teknoloji somon yetiştiriciliğinde uygulanmaya başlanmış ve iyi sonuçlar elde edilmiştir (Çaklı 2008; Çolakoğlu ve Künili 2016; Jónsson ve Viðarsson 2016). Norveç’te önemli bir kısmı su ürünleri işleme yan ürünlerinden olmak üzere, yılda yaklaşık 140 bin ton balık silaj1 üretimi gerçekleştirilmektedir. Balık unu ile balık silajı karşılaştırıldığı zaman daha ekonomik olması sebebiyle kanatlı ve büyük baş hayvan üretiminde yaygın olarak kullanılmaktadır (Rustad, 2003).

Güllü vd. (2015)'ne göre balık silajı; parçalanmış veya kıyılmış balık veya balık işleme artıklarına asit eklenerek, enzimatik faaliyetlerle sıvılaştırma şeklinde oluşturulan bir üründür. Balık silajı üretiminde, genellikle büyük miktarlarda yakalanan endüstriyel pelajik balıklar (çaça, ringa balığ1, gibi) ve balık işleme artıkları hammadde olarak kullanılmaktadır. Asit hidroliz yöntemi ile üretimi sırasında genellikle formik asit kullanıldığ bildirilmektedir (Archer vd. 2001).

Küresel balık işleme sanayileri, işlenmiş balıkların \% 60'1n dan fazlasını oluşturan balık artıklarını imha etmektedir. Çevre kirliliği ve artık problemleri yerine, bu artıkların silaj ve balık unu olarak üretime kazandırılması, hatta proteinler, hidrolizatlar, biyoaktif peptidler, kollajen ve jelatin gibi katma değeri daha yüksek ürünlere dönüştürülmesi önemli bir konudur. Protein hidroizatları (FPH) şu anda balık artıklarının endüstriyel potansiyelini düşürmeye odaklanmaktadır. Bu ürünlerin amino asit içerikleri en büyük ilgi görmektedir. FPH'nin işlevsel ve biyoaktif özelliklerine ilişkin araştırmalara yoğunlaşılması gerekliliği bildirilmektedir (Halim vd., 2016).

Balık silajının balık işleme ürün artıklarından hazırlanması için gereken süre, karışıma eklenen formik asit miktarına ve ortamın sıcaklığına bağlı olarak değişmektedir. Karışıma ilave edilen formik asit miktarının artırılması artıkların sıvılaştırma süresini kısaltmakta ancak üretim maliyetini artırmaktadır (Hossain ve Alam 2015). Silaj üretiminde depolamaya bağlı olarak pH değeri silaj ürünlerinin kalitesinin değerlendirilmesinde iyi bir indikatör olarak bilinmektedir (Tezel vd., 2016). Çalışmamız kapsamında kültür deniz balıkları işleme artıklarından formik asit hidroliz yöntemiyle elde edilen balık silajının üretim basamakları içerisindeki pH değeri 3,62-3,89 aralığında bulunmuştur (Tablo 1). Hossain ve Alam (2015) tarafindan market artıklarından formik asit hidroliz yöntemiyle silaj üretimine yönelik çalışmalarında bulgularımızla uyumlu şekilde sıvı silajın pH'sı 3,77 olarak tespit edilmiştir. Çalışmamızla uyumlu şekilde Tezel vd., (2016) tarafından bütün inci kefali ve balıkçılık işleme artıklarından üretilen balık silajlarının $\mathrm{pH}$ içeriği 3,8-4,0 aralığında bildirilmiştir. Ramasubburayan vd. (2013) tarafından deniz balıkları işleme artıklarından farklı oranlarda formik asit kullanılarak üretilen balık silajının besinsel kalite karakteri belirlenmiştir. Bu çalışmada uygulanan asit yüzdesine $(\% 2, \% 2,5$ ve \%3) bağlı olarak değişmekle birlikte pH değeri başlangıçta 5,23-4,60 aralığında, çalışma bulgularımıza uyumlu olarak 30. günde ise 3,42-3,98 aralığında bildirilmiştir. Çalışmamızla uyumlu şekilde Kristanto ve Riyadi (2018) tarafından kimyasal ve biyolojik silaj işleminin karşılaştırıldığı çalışmalarında, ton balığ 1 kafa ve içorganları kullanılarak \%3 formik asit ile 40 günlük muamele sonucu elde edilen balık silajının $\mathrm{pH}$ değeri 3,79 olduğu bildirilmiştir. Balık artıkları laktik asit bakterisi ( $L$. plantarum), sülfirik asit ve organik asit karışımları (formik asit ve propiyonik asit) (1:1) kullanılarak silaj üretimi gerçekleştirilen bir çalışmada $\% 4$ (w/w) sülfirik asit ve $\% 4(\mathrm{w} / \mathrm{w})$ organik asit karışımlarının (formik asit ve propiyonik asit) (1:1) balık silaj üretimi için en ideal oran olduğu bildirilmiştir (Pagarkar vd., 2006).

Kültür deniz balıkları işleme artıklarından formik asit hidroliz yöntemiyle üretilen balık silajının üretim süreci içerisindeki kuru madde içeriği asit hidroliz aşamasında \%44,16'iken, son aşamada ise $\% 19,60$ olarak tespit edilmiştir (Tablo 2). Ramasubburayan vd. (2013) tarafından deniz balıkları işleme artıklarından farklı oranlarda formik asit kullanılarak üretilen balık silajının besinsel kalite karakteri belirlenmiştir. Bu çalışmada uygulanan asit yüzdesine $(\% 2, \% 2,5$ ve \%3) bağlı olarak değişmekle birlikte kuru madde içeriği başlangıçta \%19,15-\%21,33 aralığında, çalışma bulgularımıza uyumlu olarak 30. günde ise \%9,33-3,98 aralığında bildirilmiştir. Madage vd. (2015) tarafından kırmızı tilapia yan ürünlerinden formik asit ile üretilen silajda kuru madde içeriği bulgularımızla uyumlu olarak $200 \mathrm{~g} / \mathrm{kg}$ (\%20) olduğu bildirilmiştir.

Çalışmamız kapsamında kültür deniz balıkları işleme artıklarından asit hidroliz yöntemiyle üretilen balık silajının protein içeriği kuru ağırlıkta \% 48,26, yaş ağırlıkta ise \% 9,44 olarak bulunmuştur 
(Tablo 1-2). Ramasubburayan vd. (2013) tarafından deniz balıkları işleme artıklarından farklı oranlarda formik asit kullanılarak üretilen balık silajının besinsel kalite karakteri belirlenmiştir. $\mathrm{Bu}$ çalışmada uygulanan asit yüzdesine bağlı olarak değişmekle birlikte kuru ağırlıkta ham protein içeriği depolamanın başlangıçta \%40,38-\%40,62 aralığında, 30. günde ise \%36,06-\%38,40 aralığında bildirilmiştir. Hossain ve Alam (2015) tarafından market artıklarından formik asit hidroliz yöntemiyle silaj üretimine yönelik çalışmalarında bulgularımızdan farklı olacak şekilde sıvı silajın protein içeriği \%12 olarak bildirilmiştir. Bu farklılığın sebebi olarak kullanılan asidin yüzde konsantrasyonu ve balık türlerindeki farklılıklar olduğu düşünülmektedir. Madage vd. (2015) tarafindan kırmızı tilapia yan ürünlerinden formik asit ile üretilen silajda yaş ağırlıkta ham protein içeriği bulgularımızla uyumlu olarak $97 \mathrm{gkg}^{-1}(\% 9,7)$ olduğu bildirilmiştir. Bulgularımızla benzer şekilde Tezel vd., (2016) yılında bütün inci kefali ve balıkçılık işleme artıklarından üretilen balık silajlarının ham protein içeriği kuru ağırlıkta sırasıyla \%47,38 ve \%37,20 olarak bildirilmiştir. Kristanto ve Riyadi (2018) tarafindan kimyasal ve biyolojik silaj işleminin karşılaştırıldığı çalışmalarında, ton balığı kafa ve iç organları kullanılarak $\% 3$ formik asit ile 40 günlük muamele sonucunda elde edilen balık silajının kuru ağırlıkta protein içeriği çalışmamızla uyumlu şekilde \%10,7 olarak bulunmuştur.

Kültür deniz balıkları işleme artıklarından hidrolize protein üretimi çalışması sonucunda son aşamada balık silajının kuru ağırlıkta ham yăg içeriği \%15,17 olarak bulunmuştur (Tablo 2). Ramasubburayan vd. (2013) tarafindan balık silajı üzerine yapılan çalışmada; kuru ağırlıkta lipit içeriği $\% 2$ asit uygulanmış örneklerde başlangıçta $\% 8,08$, depolamanın 30 . gününde ise $\% 10,66, \% 2,5$ asit uygulanmış örnekte başlangıçta $\% 8,19,30$. günde $\% 11,19$ ve $\% 3$ asit uygulanmış örnekte ise başlangıçta \%8,27, 30. günde \%12,24 olarak bildirilmiştir. Hossain ve Alam (2015) tarafından market artıklarından formik asit hidroliz yöntemiyle silaj üretimine yönelik çalışmalarında bulgularımızdan farklı olacak şekilde kurutulmuş toz halindeki silajın lipit içeriği \%33,73 olarak bildirilmiştir. $\mathrm{Bu}$ farklılığın henüz örnekten yağ fazının ayrılmamış olmasından kaynaklandığı düşünülmektedir. Madage vd. (2015) tarafından kırmızı tilapia yan ürünlerinden formik asit ile üretilen silajda yaş ağırlıkta ham yağ içeriği $76 \mathrm{gkg}^{-1}(\% 7,6)$ olduğu bildirilmiştir. Bulgularımızdan farklı olarak Tezel vd., (2016) tarafından, bütün inci kefalinden üretilen balık silajında kuru ağırlıkta ham yağ içeriği başlangıçta \%26,79 iken asit ile muamele işleminin 150. gününde \%25,93 olarak bildirilmiştir. Balıkçılık işleme artıklarından üretilen balık silajlarının kuru ağırlıkta ham yağ içeriği ise başlangıçta $\% 30,21$ iken asit ile muamele işleminin 150 . gününde \%32,71 olarak saptanmıştır. Kristanto ve Riyadi (2018) tarafından kimyasal ve biyolojik silaj işleminin karşılaştırıldığ çalışmalarında ton balığ 1 kafa ve iç organları kullanılarak $\% 3$ formik asit ile 40 günlük muamele sonucunda elde edilen balık silajının yaş ağırlıkta lipit içeriği çalışmamızla uyumlu şekilde \%1 olarak bulunmuştur.

Çalışma sonuçlarına göre üretilen balık silajının kuru ağılıkta ham kül içeriğinin \%17,01, yaş ağırlıkta ise \%3,34 olduğu tespit edilmiştir (Tablo 1). Ramasubburayan vd. (2013) tarafindan balık silajı üzerine yapılan çalışmada; kuru ağırlıkta kül içeriği farklı yüzdelerde $(\% 2, \% 2,5$ ve $\% 3)$ asit uygulanmış örneklerde \%14,04 ile \%14,60 aralığında tespit edilmiş olup bizim bulgularımızdan daha düşük olduğu görülmektedir. Hossain ve Alam (2015) tarafindan market artıklarından formik asit hidroliz yöntemiyle silaj üretimine yönelik çalışmalarında bulgularımızdan uyumlu olacak şekilde sıvı silajın kül içeriği \%3,73 olarak bildirilmiştir. Madage vd. (2015) tarafından kırmızı tilapia yan ürünlerinden formik asit ile üretilen silajda yaş ağırlıkta kül içeriği bulgularımızla uyumlu olarak 36 $\mathrm{gkg}^{-1}(\% 3,6)$ olduğu bildirilmiştir. Çalışmamızdan farklı olarak Kristanto ve Riyadi (2018) tarafindan ton balığ kafa ve iç organları kullanılarak \%3 formik asit ile 40 günlük muamele sonucunda elde edilen balık silajının yaş ağırlıkta kül içeriği \%8,5 olarak bulunmuştur.

Liyofilize edilerek kurutulmuş hidrolize protein örneklerinde yapılan mikrobiyolojik kalite analiz sonuçlarına göre toplam koliform ve psikrofil bakteri bulunmamış, toplam mezofilik aerob bakteri yükü ise 5,3-5,7 log kob/g aralığında belirlenmiştir (Tablo 3). Benzer şekilde Tezel vd. (2016) tarafından balıkçılık işleme artıklarından üretilen balık silajının asitle muamelenin 60. gününden sonra toplam aerobik mezofilik bakteri yükü, laktik asit bakteri sayısı ve maya-küf tespit edilmemiştir. Kristanto ve Riyadi (2018) tarafından kimyasal ve biyolojik silaj işleminin karşılaştırıldığı çalışmalarında, ton balığı kafa ve içorganları kullanılarak \%3 formik asit ile 40 günlük muamele sonucunda elde edilen balık silajının yaş ağırlıkta mikrobiyolojik kalite analizlerinde toplam psikrofilik aerob bakteri yükünün azaldığı bildirilmiştir.

Balık yağları, esansiyel özellikli yağ asitlerini kapsayan doymamış yağ asit (UFA) içeriği yüksek ve fosfor, magnezyum, kalsiyum gibi mineralleri de önemli oranda ihtiva eden yağlardır. Yapılan 
çalışmalar sonucunda; su ürünleri kaynaklı omega-3 yağ asitlerinin tansiyon, kanser, kardiyovasküler sistem hastalıklar, immün sistem kaynaklı rahatsızlıklarda koruyucu etki gösterdiği belirlenmiştir. Omega-3 yağ asitleri katkılı fonksiyonel ürünlerin, beslenme takviyeleri, fonksiyonel gıda, bebek mamaları ve meşrubatlarda gıda destek ürünü olarak kullanıldığ 1 da bildirilmektedir (Rustad, 2003; Strobel vd., 2012).

Yoğun proteinize balık silajı üretimi işlemi sırasında elde edilen balık yağının yağ asit analiz sonuçlarına göre otuz (30) farklı yağ asidi belirlenmiş, toplam doymuş yağ asidi miktarı \%20,64, doymamış yağ asidi miktarı ise \%70,49 olarak bulunmuştur. Ayrıca toplam n-3 yağ asidi miktarı $\% 12,15$, toplam n-6 yağ asidi miktarı \%19,87 ve n-3/n-6 oran1 \%0,61 olarak hesaplanmıştır (Tablo 4). Çalışma sonuçlarımızdan farklı olarak Tezel vd., (2016) tarafından balıkçılık işleme artıklarından üretilen balık silajının asitle muamelenin başlangıcında toplam doymuş yağ asit miktarı \%18,77 ve toplam doymamış yağ asit miktarı \%57,10 (toplam tekli doymamış yağ asit miktarı \%37,02, toplam çoklu doymamış yağa sit miktarı \%20,09), toplam n-3 \%6,67 ve n-6 3,51 olarak bildirilmiştir.

Sonuç olarak; mevcut çalışma ile su ürünleri işleme tesisi artıklarının, balık yem endüstrisi için balık unu ve yağı olarak kullanılabilecek kalitede hidrolize balık proteini ve yağı eldesine uygun olduğu, yem sanayisi için alternatif bir ham madde kaynağı oluşturabileceği, artıkların bu şekilde değerlendirilerek çevre kirliliğinin önüne geçiebileceği gibi yeni hidrolize balık proteini ve balık yağı üretim tesislerinin kurulmasıyla bölge ve ülke istihdamına önemli katkılar sağlanabileceği düşünülmektedir.

\section{TEŞEKKÜR}

$\mathrm{Bu}$ çalışma, Fatma YAMUÇ’un Yüksek Lisans tezinden özetlenmiştir. Çalışma Muğla Sitkı Koçman Üniversitesi, Bilimsel Araştırma Projeleri Koordinasyon Birimi tarafından 17/026 proje numarası ile desteklenmiştir.

\section{KAYNAKÇA}

Akçelik, M., Ayhan, K., Çakır, İ., Doğan, H.B., Gürgün, V., Halkman, A.K., Kaleli, D., Kuleaşan, H., Özkaya, D.F., Tunail, N. ve Tükel, Ç. (2000) Gıda Mikrobiyolojisi ve Uygulamaları. II. Baskı. Sim Matbaacılık Ltd. Şti., Ankara.

AOAC, (1990) Method No: 934.06, Association of Official Agriculture Chemists. Official Methods of Analysis, 15th Ed. Published by AOAC Benjamin Franklin Station, Washington, DC.

AOAC, (2005a) Method No: 928.08. Nitrogen in meat. In Official Methods of Analysis, 18th Ed., Assoc. of Official Analytical Chemist, Gaithersburg, Maryland.

AOAC, (2005b) Method 960.39. Fat (crude) or ether extract in meat. 18th Ed., Assoc. of Official Analytical Chemist, Gaithersburg, Maryland.

Archer, M., Watson, R., ve Denton, J. W. (2001) Fish Waste Production in the United Kingdom - The Quantities Produced and Opportunities for Better Utilisation. The Sea Fish Industry Authority, Seafish Technology, Seafish Report Number SR537, 1-57.

Bligh, E. G. ve Dyer, W. J. (1959) A rapid method of total lipid extraction and purification. Canadian Journal Biochemistry Physiology. 37: 911-917.

Çaklı, Ş. (2008) Su ürünleri işleme teknolojisi (Alternatif Su Ürünleri işleme Teknolojileri), Ege Üniversitesi Yayınları, Su Ürünleri Fakültesi Yayın No: 77, İzmir.

Borghes1, R., Arruda, L.F. ve Oetterer, M. (2008) Fatty acid composition of acid, biological and enzymatic fish silage. Boletim do Centro de Pesquisa de Processamento de Alimentos. 26: 205-212.

Çolakoğlu, F. ve Künili, İ.E., (2016) Su Ürünleri Atıkları ve Değerlendirme Olanakları, Dünya Gıda Dergisi, 1: 58-64.

FAO, (1992), The State of Food and Agricalture. FAO Agriculture Series No: 25, Roma.

Güllü, K., Güzel, S. ve Tezel, R. (2015) Producing silage from the industrial waste of fisheries. Ekoloji, 24(95): 40-48.

Gündüz, H., Öztürk, F., Hamzaçebi, S., Akpınar, M.D. (2018). Su Ürünleri işleme atıklarının değerlendirilmesi. Aquat. Sci. Eng., 33(1): 1-5.

Halim, N. R. A., Yusof, H. M., ve Sarbon, N.M., (2016) Functional and bioactive properties of fish protein hydolysates and peptides: A comprehensive review. Trends in Food Science \& Technology, 51: 24-33.

Ichihara, K., Shibahara, A., Yamamoto, K., \& Nakayama, T. (1996). An improved method for rapid analysis of the fatty acids of glycerolipids. Lipids, 31, 535-539.

Goddard, J.S. ve Perret, J.S.M. (2005) Co-drying fish silage for use in aquafeeds. Animal Feed Science and Technology. 118: 337-34. 
Hossain, U. ve Alam, A.K.M.N. (2015) Production of Powder Fish Silage From Fish Market. Wastes. Saarc J. Agri, 13(2): 13-25.

Jónsson, A., ve Viðarsson, J. R,. (2016) By-products from whitefish processing. Matis - Food Research, Innovation \& Safety, 1(2): 1-36.

Kılınç, B. (2007). Balık atıklarının değerlendirilmesi. Su Ürünleri Dergisi, 24(3): 315-319.

Kristanto, G.A. ve Riyadi, A. (2018) Waste minimization of fishery industry in Muara Angke, Jakarta: a comparison of chemical and biological silage processes. IOP Conf. Ser.: Earth Environ. Sci. 200, 012021:1-6.

Madage, S.S.K., Medis, W.U.D. ve Sultanbawa. Y. (2015) Fish Silage as Replacement of Fishmeal in Red Tilapia Feeds. Journal of Applied Aquaculture, 27: 95-106.

Mol, S. (2004) Su ürünleri alternatif ürün sanayi. Su İşleme Teknolojisi, Varlık, C. (Ed.). İstanbul Üniversitesi, Su Ürünleri Fak. Yayın No:7, 441-476.

Pal, G.K. ve Suresh, P.V. (2016) Sustainable valorisation of seafood by-products: Recovery of collagen and development of collagenbased novel functional food ingredients. Innovative Food Science \& Emerging Technologies, 37: 201-215.

Pagarkar, A.U., Basu, S., Mitra, A., Sahu, N.P. (2006) Preparation of biofermented and acid silage from fish waste and its biochemical characteristic. Biotechnology and Environmental Sciences, 8(2): 381- 387.

Ramasubburayan, R., Iyapparaj, P., Subhashini, K.J., Chandran, M.N., Palavesam, A. ve Immanuel, G. (2013) Characterization ve nutritional quality of formic acid silage developed from marine fishery waste and their potential utilization as feed stuff for common carp cyprinus carpio fingerlings. Turkish Journal of Fisheries and Aquatic Sciences 13: 281-289.

Rustad, T. (2003) Utilisation of marine by-products. In Electronic Journal of vironmental, Agriculture and Food Chemistry, 2 (4): 458-463.

Sekin, Y. ve Karagözlü, N. (2004) Gıda Mikrobiyolojisi. Gıda Endüstrisi İçin Temel Esaslar ve Uygulamalar. Klaus Pichhardt 4. Basımdan Çeviri. Literatür Yayıncılık: 115, İstanbul, 358s.

Strobel, C., Jahreis, G. ve Kuhnt, K. (2012) Survey of n-3 and n-6 polyunsaturated fatty acids in fish and fish products. Lipids in Health and Disease. 11: 144- 152.

Taylor, T. ve Alasalvar, C. (2002) Improved utilisation of fish and shellfish waste. Seafoods - quality, technology and nutraceutical applications. Springer. 123- 136.

Tezel, R., Güllü, K., Alişarlı, M., Ekici, K. ve Güzel, Ş. (2016) A Study On Chemical ve Microbiological Composition of Silage Made of Industrial Fisheries Processing Waste. Mugla Journal of Science and Technology, 2(1) : 30-37.

Ünlütürk, A. ve Turantaş, F. (2002) Gıdaların Mikrobiyolojik Analizi. II. Baskı. Meta Basım Matbaacılık Hizmetleri. Bornova. İzmir.

Varlık, C., Uğur, M., Gökoğlu, N. ve Gün, H. (1993) Su Ürünlerinde Kalite Kontrol İlke ve Yöntemleri. Gıda Teknolojisi Derneği, Yayın No:17, İstanbul, 174 ss. 